\title{
Beyond the peace lines: conceptualising representations of parks as inclusionary spaces in Belfast, Northern Ireland
}

DOI:

10.3828/tpr.2019.13

\section{Document Version}

Accepted author manuscript

Link to publication record in Manchester Research Explorer

Citation for published version (APA):

Mell, I. (2019). Beyond the peace lines: conceptualising representations of parks as inclusionary spaces in Belfast, Northern Ireland. Town Planning Review, 90(2), 195-218. https://doi.org/10.3828/tpr.2019.13

\section{Published in:}

Town Planning Review

\section{Citing this paper}

Please note that where the full-text provided on Manchester Research Explorer is the Author Accepted Manuscript or Proof version this may differ from the final Published version. If citing, it is advised that you check and use the publisher's definitive version.

\section{General rights}

Copyright and moral rights for the publications made accessible in the Research Explorer are retained by the authors and/or other copyright owners and it is a condition of accessing publications that users recognise and abide by the legal requirements associated with these rights.

\section{Takedown policy}

If you believe that this document breaches copyright please refer to the University of Manchester's Takedown Procedures [http://man.ac.uk/04Y6Bo] or contact uml.scholarlycommunications@manchester.ac.uk providing relevant details, so we can investigate your claim.

\section{OPEN ACCESS}




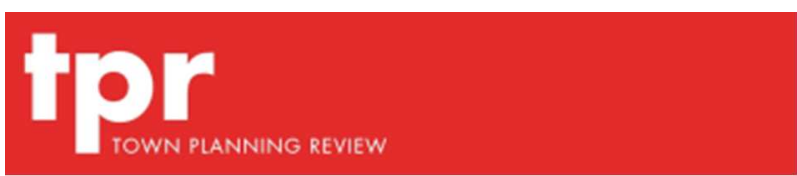

\section{Beyond the peace lines: conceptualising representations of parks as inclusionary spaces in Belfast, Northern Ireland}

\begin{tabular}{|r|l|}
\hline Journal: & Town Planning Review \\
\hline Manuscript ID & TPR-11-17-OA-0049.R3 \\
\hline Manuscript Type: & Original Article \\
\hline Keywords: & $\begin{array}{l}\text { defensive architecture, urban development, community, spatial } \\
\text { representations, parks }\end{array}$ \\
\hline Abstract: & $\begin{array}{l}\text { Belfast is a city of extremes in terms of its political, historical, cultural, and } \\
\text { urban development. Due to political unrest its spatial form has been } \\
\text { subject to extensive redevelopment, and the imposition of defensive } \\
\text { architecture. Within this narrative, parks have been overlooked; less } \\
\text { evidence is available as to whether public spaces, and specifically parks, } \\
\text { can be repositioned as spaces of inclusivity and communal interaction. To } \\
\text { examine whether parks can facilitate a greater sense of community and } \\
\text { identity, this paper employs a novel conceptualisation using the theoretical } \\
\text { framing of Foucault (1991), Lefebvre (1991), Lynch (1960) and Newman } \\
\text { (1973) to examine how representations of physical space influence the } \\
\text { behaviour, use and value of parks. It further evaluates how each can be } \\
\text { applied to our understanding of the value of parks using Belfast as a case } \\
\text { study. }\end{array}$ \\
\hline
\end{tabular}




\begin{abstract}
Belfast is a city of extremes in terms of its political, historical, cultural, and urban development. Due to political unrest its spatial form has been subject to extensive redevelopment, and the imposition of defensive architecture. Within this narrative, parks have been overlooked; less evidence is available as to whether public spaces, and specifically parks, can be repositioned as spaces of inclusivity and communal interaction. To examine whether parks can facilitate a greater sense of community and identity, this paper employs a novel conceptualisation using the theoretical framing of Foucault (1991), Lefebvre (1991), Lynch (1960) and Newman (1973) to examine how representations of physical space influence the behaviour, use and value of parks. It further evaluates how each can be applied to our understanding of the value of parks using Belfast as a case study.
\end{abstract}

Key words: parks, defensive architecture, urban development, community, spatial representations 


\section{Introduction}

Urban parks are valued assets to city authorities, communities and businesses. They provide locations for social interaction, promote biodiversity, enable engagement with nature, and help generate income. However, within urban planning discussions, and specifically those focused on place making, parks, as multi-functional urban spaces, are often downplayed compared to other elements of the built environment (CABE Space, 2005). Moreover, in cities where socio-economic change or political uncertainty exists, essential infrastructure is given priority, with "landscape" as a public asset marginalised (Rybczynski, 1999). Academic and practitioner literature argues that parks hold a crucial role in understanding urban liveability (Tate, 2015). These benefits include providing ecosystem services to address climate change, supporting increased real estate values, and acting as locations that promote health and social inclusion. Unfortunately, in some locations, for instance Belfast, Detroit, and Jerusalem, local governments' ability to balance changing demographics and infrastructure provision with the management of high quality parks is fraught (Bollens, 2018).

Developing a more nuanced understanding of parks' role in promoting inclusivity, this paper evaluates two key aspects of urban planning. First, it discusses whether a consensus exists in existent literature regarding how parks are valued as spaces that promote inclusivity. Second, it presents a novel conceptual framing for parks to aid our appreciation of how physical space influences behaviour and use simultaneously. This analysis is presented through examining four articulations of spatial understanding, which are used to question assumptions of the inclusivity/exclusivity of parks. Specifically, Newman's (1973) defensible space thesis, Lynch's (1960) social signifiers, Lefebvre's (1991) differentiation of production and representations of space, and Foucault's (1991) discussion of disciplinary architecture. Each has been used independently to evaluate the meanings ascribed to urban spaces, and to a lesser extent parks, but not collectively to facilitate a more holistic understanding of the interaction of physical space with psychological and/or socio-cultural meanings placed on parks. This promotes the creation of a set of additional considerations that can be used to debate the utility of parks currently being employed in policy and practice-based thinking. Staeheli and Mithcell (2008) argue that inclusion/exclusion are not absolute terms but located within wider discussions of power, practice and institutions - issues that permeate urban planning discourses in contested locations (Bollens, 2018). Plans and policies thus provide an overarching approach to parks' management, and subsequent use, but in many places the contested nature of public space is less well-defined meaning that the deeper social value of parks is excluded from decision-making.

To investigate whether parks are socially and/or communally inclusive, the following reflects upon how spatial configuration - the physical/structural infrastructure, the behavioural and societal 


\section{Reconceptualising parks}

Although a wealth of literature exists promoting the value of parks within urban areas (Tate, 2015), there is a parallel discussion which questions their utility in cities where financial, political or sociocultural influences are increasingly constrained (Dempsey, Smith, \& Burton, 2014). Thus, an ongoing debate exists within urban planning as to whether cities should invest in parks, and whether the benefits they provide in terms of liveability can be calculated (CABE Space, 2005). Such discussions highlight an ongoing reluctance to see beyond economic development or investment in infrastructure perspectives as the primary approaches to urban growth. Parks' value to cities' climates, populations and economies have become marginalised within broader planning debates; they are not viewed as a political priority (Mell, 2018). A significant proportion of this conversation focuses on the financial commitments required to manage multi-functional landscapes. In many UK and North American cities financial pressures faced by local government due to recession and/or demographic change have placed severe restrictions on parks' development and management (Low, Taplin, \& Scheld, 2005). However, evidence from Berlin and Vancouver suggests that cities that maintain high-quality and accessible physical environments are considered more attractive by businesses and communities (Lachmund, 2013; Tate, 2015). Thus, parks can be a key resource in marketing a city as inclusive and liveable.

Within urban development discussions parks can be considered from a socio-cultural perspective. This argues for an appreciation of parks that moves beyond them being a simple 
configuration of ecological elements to a more nuanced understanding of them as communal activity "hubs". CABE Space (2005) proposed that cities' park-networks is the spatial location or spaces that people attach meaning to through exposure and interaction. Consequently, communities identify parks as places that provide individual and collective benefits - additional to other forms of built infrastructure (Nassauer, 1995; Rishbeth et al., 2018). In many cases this includes an acknowledgement of how their design and management influences engagement with them, an issue downplayed in many planning policies (Gaffikin et al., 2010). Moreover, the recent Nesta (2016) Learning to Rethink Parks report in the UK proposed that local government, planners, and communities need to reconsider the value placed on parks to plan them more effectively. In addition to reflecting on management NESTA argues that their location and amenities are key factors influencing use, which need to be considered more frequently in both strategic and localised urban development discussions.

Further complexity is added to this process in cities with contested landscapes. In such locations variation exists in how cities plan for the management of parks and other public spaces, nominally in a form of social control, i.e. security infrastructure, and how local communities interact and place value on landscape (Shirlow, 2006). The demographic and cultural profile of an area, as well as the religious or political affiliation of its communities have been viewed as key indicators of place attachment. Consequently, when cities exhibiting such characteristics, are planning for growth, a nuanced understanding of the social significance of place to local people is required if parks are to be inclusive and functional (Bollens, 2018).

Parks are investigated within this paper because, despite being civic spaces that provide financial and socio-cultural value to society, they have been marginalised within policy discussions (Rybczynski, 1999). Parks also address the needs of different user groups simultaneously, even in areas of conflict or contestation. Parks may be spaces of "common belonging", which have historically been at a premium in cities such as Jerusalem or Belfast due to economic, physical or sectarian-cultural divisions (Bollens, 2018; Gaffikin et al., 2010). Within the context of this paper, and the Belfast case study presented, parks are proposed to hold communal value, and to reflect the promotion of "shared space"1" outlined within the Belfast Agenda (BCC, 2014; Neill et al., 1995).

\section{Urban planning in Belfast: The Troubles and beyond}

Our evolving understanding of urban parks, and specifically in Belfast, needs to be reflective of the nuanced negotiations between formal and community-led cultural understandings of physical space,

\footnotetext{
1 "Shared" space in Belfast refers the joint use of spaces by both Catholic and Protestant communities, and is not a reference to the interaction of all sectors of society with a public space (Hickey, 2014).
} 
including the defensive architecture and policy frameworks used to contextualise development (Abdelmonem and McWhinney, 2015; Shirlow and Murtagh, 2006). Whilst an extensive literature exists debating the influence of defensive architecture and communal segregation in cities including Berlin, Jerusalem and Belfast (Bollens, 2018; Cunningham, 2014; Shirlow, 2006), there has been limited discussion of whether, compared to other built infrastructure, parks possess the same or an alternative, (and non-politicised), set of values.

Belfast, and Northern Ireland in general, have been characterised by division and sectarianism for over a century (Murtagh, 2002). This has been manifested in opposition to, and violence directed at, the British government, its armed forces and the police, although, as this paper argues, a more contemporary approach to landscape is developing. In addition, Belfast is spatial divided, whereby predominately Catholic (republican) and Protestant (loyalist or unionist) communities are identified with specific areas of the city: nominally, Catholics to the west and Protestants to the east. Belfast can be divided along ethno-community lines; exhibited through the spatial articulation of urban development by the city's planners (See Fig. 1).

The city's segregation has been influenced by the armed struggles associated with the aforementioned communities, meanings that the city's landscape has been compartmentalised historically (Murtagh, 2002). Throughout the 1960-1980s large tracts of the city were controlled locally by communities to the exclusion of city officials, the police and British Army (Shirlow and Murtagh, 2006). The city's militarisation and the restrictions this placed upon communities significantly influenced the escalation of violence. Paradoxically, this led to greater calls for control by the armed forces from some Protestant communities (Cunningham, 2014). Due to ongoing violence, a series of physical structures were developed in areas of increased tension known as "interface" zones. These structures: "peace lines" or "peace walls" acted as physical, and importantly, psychological boundaries between communities. Their impact was four-fold:

1. The peace walls/lines led to changes in behaviour, limiting where and how individuals and/or communities could engage with different parts of the city;

2. It reinforced perceptions of division between Catholic and Protestant communities which felt victimised by the state and/or other communities;

3. It reinforced community identities; the peace walls/lines were perceived as limiting the incursion of other "communities", thereby promoting idiosyncratic interpretations of political and historical facts; and

4. Public spaces were designed to limit interaction, promote surveillance and enable effective management of integration between communities in the city centre and interface zones.

(Gaffikin et al., 2010; Murtagh, 2011; Neill, 2006; Shirlow and Murtagh, 2006) 
The divisions caused by physical segregation have been exacerbated over the last twenty-five years as Belfast has seen significant shifts in its economic and demographic profile. The city's industrial core, focussed on engineering, has been subject to closures, like other UK cities (Murtagh, 2002). Community identities associated with that industrial heritage have also been impacted upon by this cleavage of attachments between place and socio-economic activity. This is an important element of identity as Shirlow $(2006,102)$ describe, '...determining the mediums through which Belfast's residents transform daily occurrences and emotions into a symbolic system of territorial attachment'. Consequently, there is a perceived need to constantly negotiate access to Belfast's contested social spaces. This process is attributed significance by communities because areas of east and west Belfast hold historical associations with communal rights to access the city, both physically and psychologically, which are now being challenged (Shirlow, 2006).

Changes in the demographic profile of Belfast have also led Belfast City Council (BCC) to reassess the feasibility of maintaining segregated areas (Leonard, 2004), as the city's Catholic community has grown whilst the Protestant population has fallen (Murtagh, 2002). This has placed pressures on Belfast's housing stock, as the growing Catholic community require accommodation and are more mobile compared to some Protestant communities. As Murtagh $(2011,1120)$ argues "Residential mixing is thus presented as a moral, rational and political project in which material prosperity will overwrite tribal allegiances in the creation of new social and physical spaces". Moreover, Belfast's growing, socially mobile middle class is engaging with services, amenities, and housing in different ways to established communities. Whilst this has created a greater proportion of shared spaces or interface communities, where residential areas meet at confluence points, there has been a corresponding concentration of insularity within some Protestant communities, which feel that their identify is being challenged (Shirlow, 2006).

The city's response to the changing demographic and economic aspirations of Belfast has been to embark on a bold process of urban regeneration (BCC, 2014). This has focussed on reestablishing the denuded docklands as a cultural hub and promoting city-centre economic development opportunities (Neill, 2006). It also moved discussions away from sensitive placemaking issues associated with specific localities in the east and west of the city, to designing inclusivity into public spaces (Gaffikin et al., 2010). This process of regeneration may neutralise the associations of segregation that permeate the city's history (Madden, 2010). It also required a shift in emphasis, via the Belfast Agenda (BCC, 2014), from one of bureaucratic control over the city's physical form to one of reinforcing the principles of shared civic spaces (Banerjee, 2001; Murtagh, 2002). Within this discussion there remains, however, concern that even in "shared" spaces, 
inclusivity is framed by geo-spatial and religious affiliations (Madden, 2010). Shirlow $(2006,100)$ questions this process noting ...policy-making has been selective and lacks a critical commitment capable of addressing the injustices of segregation and socio-spatial exclusion. Without such vision, Belfast will never be repositioned as a progressive city.

Shirlow's assessment illustrates a lack of complementarity between Belfast's reframing as an economically prosperous city and the delivery of activities required by communities to make it liveable. This is most noticeable in areas of east and west Belfast where access to high quality housing, social services and green space is most varied (Green et al., 2005). Moreover, there has been additional criticism of the city's redevelopment agenda because it aims to increase interaction and permeability between communities. It could be argued that such objectives fail to address socioeconomic needs of all the city's population, as Gaffikin et al. (2010) ask, is the promotion of intercommunalism something to aspire to in Belfast? Accordingly, although the city is attempting to facilitate improved quality of life through the use of community-centred design which emphasises access and the provision of recreational amenities of which parks are a key component, it may also reinforce existing segregationist problems by engineering a pro-integrationist policy rather than addressing socio-cultural issues (Komarova and Bryan, 2014).

In the following sections, we extend this discussion. In debating whether Belfast's parks can be conceptualised as inclusive spaces, the principles of architectural control, management and the social significance of space outlined by Lynch, Newman, Lefebvre and Foucault are integrated to examine alternative narratives of inclusion.

\section{Newman's defensible spaces}

Newman's conception of "defensible spaces" promotes a territorial definition of urban areas, reflecting the influence of both inhabitants and users of a given location. Through an ongoing engagement with these spaces, similar to Jacobs' (1961) approach to communal observation, places are sub-divided into zones that facilitate custodianship by specific groups. Whilst both Jacobs and Newman focussed on housing (Perkins et al., 1993), we extend their analysis to assess public parks' interactivity. Defensible spaces are proposed to limit the vulnerability of individuals through a form of self-policing that distinguishes acceptable from unacceptable behaviour (Burgess et al., 1988). However, uncertainty remains over whether a causal relationship exists between designed security, interaction with built environments, and communal behaviour (Brunson et al., 2001). Newman's (1973) thesis states that urban design focussed primarily on density, and open, yet mono-functional 
green spaces, creates exclusionary spaces. This was achieved through physical infrastructures' ability to limit the circulation of people and activities. In addition, defensive architecture may be a permanent reminder of conflict where segregation has been explicitly designed into the physical landscape (Gaffikin et al., 2010).

An analysis of the physical layout of parks, and their location within cities' wider spatial structures has been viewed as a comparable symbol of segregation (Byrne and Gormley-Heenan, 2014). Additionally walls, derelict spaces, and mono-functional green space have been used as proxies for the exclusionary nature of public spaces and parks (Murtagh, 2002). Discussions of defensible spaces support a dualistic understanding of space, where it can be read as communal or aligned with personal symbolic markers that identify rights of use and ultimately ownership (Perkins et al., 1993). Socio-cultural markers may thus have a dual meaning. They can symbolise tensions between a city and its communities due to conflicting perceptions of control over uses, or they can reinforce communal homogeneity allowing territorial claims to space to be made (Banerjee, 2001). Through a process of formal/informal sub-division, sites become segregated, placing them in opposition to the perceived inclusivity of parks (Abdelmonemand McWhinney, 2015).

Where sites have been designed to limit mono-functional uses, greater interaction and associated value has been reported (Abdelmonem and McWhinney, 2015). As Brunson et al. (2001) contend, designing in "functionality" through aesthetic, access and amenity provision for different members of the community, potentially limits the creation of exclusionary spaces. Increased functionality provides potential for peoples' greater interactivity with parks. Unfortunately, Abdelmonem and McWhinney (2015) identify that, even where multi-functional spaces are created, "invisible" social signifiers of ownership can still shape the use of parks, such as those associated with specific sports, community or recreational activities. Thus, defensible architecture can be supplemented with additional ethno-cultural barriers to use, which often go unreported in management discussions. Where such behaviour occurs community observation can act as a greater deterrent to anti-social behaviour than formal policing or investment in defensive architecture (Burgess et al., 1988).

\section{Lynch's social signifiers of urban meaning}

Whilst policing parks would be a visible sign of formal control, Lynch's (1960) proposals regarding social signifiers can be a more appropriate method of interpreting how ethno-cultural practices influence behaviour both within and outside parks. Historically, contested cities have placed significant emphasis on ethno-cultural signifiers, using walls, roads and other cultural symbols as central components in this analysis (Bollens, 2018; Murtagh, 2002). Lynch's analysis of urban form identified existing signifiers (positive and negative), as holding communal meaning. This provides 
spatial parameters to examine our understanding of urban areas; our resultant knowledge is subsequently used to frame perceptions of parks and public spaces. This process is evolutionary, as social signifiers are a fluid component within existing city-planning and communal interactions with landscape, not static as Lynch originally proposed (Newman, 1973). It can be argued that parks hold a resonance that enables people to navigate the physical boundaries and their social ties to parks; promoting alternative interpretations of cities' landscapes (Silva Gouveia et al., 2009).

The use of social signifiers enables people to identify sites with corresponding actions or ethnocultural events, thus creating mental maps of inclusion/exclusion (Nassauer, 1995). Such maps are constructed individually, however, collective understandings of segregated space are noticeable in many cities, suggesting that explicit communal interpretations of space have also been developed (Bollens, 2018). When discussing parks in predominately Catholic/Protestant, AfricanAmerican/Latino/Caucasian or Jewish/Palestinian areas, such a dualistic approach is interesting, as communities engage with their personal interpretations of a site whilst contextualising it within broader understandings of place (Cunningham, 2014; Nagle, 2009). Thus, even within established communities, variation in levels of internal complexity in the use and value placed on parks can be identified similar to Rishbeth et al's (2018) assessment of ethnic and minority groups' park usage in the wider UK.

Nassauer (1995) extended this discussion, stating that such interpretations can be compartmentalised to sub-divide neighbourhoods or parks into specific territories. Thus, significance becomes increasingly "private" or "individualised", even when located within a communal narrative. It is crucial, though, to maintain a sense of perspective when scaling cognitive understanding from individuals to communities because, as 'Ledrut (1973) [stated]... the image in its social context... loses its meaning when out of context... the image and the context are inseparable' (Neuman, 1998, 66). The use of parks could therefore be grounded in different motivations compared to the use of other parts of a city (Banerjee, 2001).

Whilst Nassauer (1995) proposed that cognitive maps can be scaled from individuals to communities (or society), social signifiers and community understanding are symbiotic. The nature of territorial ownership has, however, been shaped by community interactions with spaces associated with civic tension, and the official and unofficial reactions of the state and law enforcement policies (Nagle, 2009). Thus, communities self-identify with spaces of ethno-cultural significance and may claim them as secular or segregated (Murtagh, 2011). Consequently, attempts to redevelop such sites, redefine community ties or move existing ethno-cultural boundaries can cause conflict. Furthermore, self-identification with spaces based on class, age or cultural association illustrate a form of agency (Abdelmonem and McWhinney, 2015). Such agency provides key 
signifiers of ethno-cultural ownership which, are essential to ongoing interpretations of place and space (Neill, 2006).

\section{Lefebvre's representational space and spatial practice in Belfast}

In addition to communally focussed social signifiers, local planning officials have "savoir" of how places function (Lefebvre, 1991). However, local communities are also engaged with in-depth understandings of how places work individually, communally and politically. Conceptually, there is an implementation gap between how development is structured within local planning frameworks and experienced by the public (Graham and Healey, 1999). Thus, although city governments plan for population, commercial and transport growth, gaining community support for such measures can be difficult due to the complexity of communal histories associated with specific locations. Roads, interface zones, and neighbourhoods are all established signifiers of socio-political histories (Lefebvre, 1991). Subsequent attempts to promote neutrality within these areas have been developed but stakeholders do not always see this as rational. The promotion of a 'common civic identity' (Bryan, 2003, 264) in many cities' that foregrounds discussions of development attempts to establish a singular civic identity (Nagle, 2009), but is not supported by all communities (Murtagh, 2002). Lefebvre (1991) analysis of the politics of place, provides a useful counterpoint to Lynch's (1960) discussion of signifiers. Lefebvre argues that understandings of urban areas can be conceptualised through three approaches:

1. Spatial practice - providing a continuity and understanding of the physical world around us

2. Representations of space - codes, signifiers and experiences that influence our current understanding of space, which is more abstract but influences our lived experience

3. Representative space - more complex, this relates to lived experience with coded signifiers

Lefebvre suggests that, in areas associated with conflict or segregation, interpretations of place become subject to locational and societal evaluations, and are part of ongoing processes of place creation and negotiation. As such, there is an evolution of how urban areas are and should be planned, managed and used (Nagle, 2009). Furthermore, this perspective can be reassessed to discuss how choices made by communities in terms of their interactions with the physical landscape illustrate the complexity of values placed upon parks (Abdelmonem and McWhinney, 2015). However, actioning such a fluid interpretation is often challenged by ongoing dissent between stakeholders engaged in conflicting activities (Boal, 1994). Thus, the roles of participation and intercultural exchange that underpin the interactions and subsequent valuation of landscapes are 
difficult to control, and relate more directly to Lefebvre's conception of spatial practice (Nagle, 2009). The experiential nature of Lefebvre's "representative space" is potentially a more apt way to debate interactions with urban landscapes, as it aligns lived experience with ongoing assessments of community identities and formal planning structures.

Lefebvre's discussion of spatial planning argues that there is a cycle of engagement, discussion and reinforcement of common and idiosyncratic ideals. This is reflected in the cleavage between normative and alternative views of community interpretations of their rights to a city, which is central to our understanding of place (Nagle, 2009). Consequently, perceptions of the societal meanings of parks can be viewed as a multi-layered process of experience and assessment (Berger, 1972). The creation and continued support for division based on identity can be challenged through redevelopment processes. Within this debate "representations" of divided spaces produced through visible or physical boundaries are displayed as attachments to specific landscape features that limit interaction and reinforce psychological divisions (Gaffikin et al., 2010; Morrissey and Gaffikin, 2006). Parks may be the exception, as they are proposed by cities to look beyond segregation towards a more apolitical promotion of urban inclusiveness (Abdelmonem and McWhinney, 2015).

Through Lefebvre's approach, we propose that an understanding of parks may be more appropriate compared to that of other built environment conceptualisations, as the development and subsequent use of shared spaces moves away from homogeneous representations of space to a more representative approach that incorporates evolving interactions with landscape. The role of experience in the reassessment of social interpretations is critical in this process allowing planners, city officials, and communities to think about parks as spaces with alternative social, ethno-cultural and environmental meanings (Hetherington, 1998). Parks can, therefore, offer multi-functional uses because, as Berger (1972) describes, they can be an expression of both patronage and lived experience.

\section{Foucault and disciplinary architecture}

Knowledge of place is politically and socially constructed to the point where dominant perceptions of segregation remain in many cities (Rallings, 2014). This, however, can be considered dependent upon social, ethnic or political perspectives, rendering ongoing place-making within formal planning agendas complex (Shirlow and Murtagh, 2006). Furthermore, through the process of development and the use of spaces, communal identifications can be challenged. Stakeholders in many cities have resisted this shift away from the "local", instead reinforcing their rights to a city (Hickey, 2014).

Our understanding of defensive architecture can establish institutional agency by which government, through the manipulation of physical space, maintains control over a city's population. 
As Foucault $(1977,172)$ states, architecture 'operate[s] to transform individuals: to act on those it shelters, to provide a hold on their conduct... to make it possible to know them, to alter them'. Communities also monitor and moderate behaviour, '...invest[ing] the built environment with myriad codes of ethnicity amid a militant politics of defiance and resilience' (Gaffikin et al., 2010, 495). Whilst, defensive architecture creates barriers between communities, they act as signifiers of segregation, and "infrastructure" may reinforce communal resistance to political systems. By regulating movement, these structures establish platforms of surveillance within and across community boundaries (Byrne and Gormley-Heenan, 2014). The limiting of permeability between communities by reinforcing psychological "borders" located alongside physical "boundaries" promotes an observational society; limiting freedom of movement (Gaffikin et al., 2010). With the creation of more porous urban landscapes, public spaces, and particularly parks, can provide locations of interaction for communities. This maybe a tacit form of control presented through formal planning practices and informal uses of landscape to shape experiences of space. Cities though remain subject to ongoing regulatory and community control, which has been historically employed to monitor behaviour therein (Pløger, 2008).

Spaces can however lose their anonymity as communal identities, either protective or inclusionary, are attached to them. The potentially abstract notion of "surveillance" can also limit the requirements for institutions to be physically located in situ to control community boundaries (Byrne and Gormley-Heenan, 2014). This promotes a level of psychological control, linked to selfregulation, leading to a conscious dislocation between people and the wider landscape, restricting use by some communities. The discussion of parks provides an alternative view, as they are locations of multiple uses and functions that support more heterogeneous sets of communities (CABE Space, 2005). Thus, whilst physical manifestations of control remain leading to self-regulation of personal or communal actions (Foucault, 1991), parks are located parallel to these discussions, as they have more limited or less visible histories of segregation.

Despite this variation, Pickett $(2005,106)$ argues that 'living under consensual restraints is a critical part of self-determination', therefore the development of a consensual approach to communal engagement can leave individuals vulnerable to the influence of external factors. Moreover, although we can identify normalised, self-fulfilling, and "ritualistic" approaches to control based upon historical power relations between communities, space and city authorities (Pickett, 2005), there is greater fluidity in how people access parks, the activities they undertake there and with whom. Unfortunately, the development of facilities that service only a singular community has been perceived to reinforce broader divisions, and fulfils the that space works through 'the form of the visible, as opposed to the form of whatever can be articulated'. (Foucault, 1991, 204) explored 
this notion, stating 'the panopticon functions as a kind of laboratory of power'. ${ }^{2}$ Such an interpretation has a spatial dynamic, moving from individuals, through communities, and visibly influences the management of landscape and the subsequent behaviour of a city's population. However, the validity of this process within parks can be queried if we question the rationale that the authority exerted by government or its communities is the primary factor controlling behaviour in these locations.

The following section uses Lynch, Newman, Lefebvre and Foucault to rethink how Belfast's parks are used, and explores how physical space and the ethno-cultural significance of public space impacts upon their value.

<Fig. 1. Ward boundaries, predominant religion and location of parks in Belfast> $<$ Fig. 3. Alexandra Park> <Fig. 4. Musgrave Park>

$<$ Fig. 5. Defensive architecture and greenspace>

\section{Re-conceptualising the value in Belfast's parks}

As a consequence of both the visible, and invisible communal management of space, 'geography matters in Belfast in an overt, public and meaningful way' (Shirlow, 2006, 107). Community associations with defined areas of the city are central to their understanding of division. Partially, this is achieved by the territorialisation of space through visible signs of segregation, i.e. peace walls. Additionally, invisible demarcations of territory, such as areas of Musgrave (Fig. 4) and Ormeau Parks, which are culturally controlled, are also noticeable (Murtagh, 2002). The latter are subtler and therefore more difficult to quantify, as they include informal socio-culturally designated sections of parks, their walkways, or access to amenities and sports/recreational facilities. Falls Road, and Victoria parks located in predominately Catholic west and Protestant east Belfast respectively, can be considered more formal examples of the physical territorialisation of space associated with Newman's thesis due to their location but not necessarily their design. Parks in the south of the city such as the Botanic Gardens have been reported as being subject to more socially variable uses; they are not dominated by a single community reflecting the changing nature of valuation associated with Lynch (Abdelmonem and McWhinney, 2015). Additionally, Musgrave Park (Fig. 4) in south Belfast has been subject to ongoing debate regarding its "Catholicisation" following the development of Gaelic sports facilities. This integrates changes to the spatial form of the site with a

\footnotetext{
${ }^{2}$ This includes the heightened sense of surveillance issues under the securitised state, the physical manifestations of this as peace walls, and changes in communal behaviour, which is reflective of state and communal control.
} 
rationalisation of the lived experience of the park, as proposed by (Lefebvre, 1991). Waterworks and Alexandra Parks (Fig. 3) are potentially the most complicated examples of this process, as they are located within a north Belfast interface zone and exhibit, visible, (the peace wall, Fig. 3), and invisible, (areas around the fishing lake), signs of territorialisation; viewed by some locals as segregating the area's communities. This suggests a continuum of interpretation may exist that utilises physical space and psychological and social meanings associated with Newman and Lynch.

Understanding Belfast's urban form can be framed by an evolving reflection of development that moves away from control and conflict, and strives to remake the city's physical landscape a location for investment based on inclusivity (Neill, 2006). This talks to Belfast's many communities of interest, and asks who parks and other public spaces are for: the city, its development agenda (and private investors), or its residents (Banerjee, 2001; Gaffikin et al., 2010)

Within this discussion, the ways in which we approach perceptions of parks can be used as an analytical tool through which the ongoing aspirations of developers, politicians, and communities are evaluated to assess how they negotiate complex ethno-cultural histories of community interactions with space, place and city planning. By characterising communal uses of these spaces (Lefebvre, 1991), we argue that socio-cultural values associated with parks become central to appreciating their social significance. By reflecting on the Belfast development agenda (BCC, 2014), including the removal of defensive architecture, it is possible to conceptualise variability in perceptions of public space, and illustrate potential options that BCC can employ to focus future investment on inclusivity. Neill et al. (1995) argue that urban regeneration and the design of spaces, specifically green spaces, can be a barometer of positive social, economic, and ecological change. The $f 11.7$ million regeneration of the former army barracks at the Girdwood hub located between the Falls and Shankill Roads in west Belfast and the ongoing negotiations over the $£ 400$ million redevelopment of the former Sirocco site in east Belfast are two such examples (Cunningham, 2014; O'Dowd and Komarova, 2011). That said, ongoing pro-unionist activities along the Connswater Greenway ${ }^{3}$ in east Belfast, i.e. $12^{\text {th }}$ July bonfires in Orangefield Park reinforce a sense of localised ownership, despite the greenway's spatially diverse geography (Prior et al., 2014).

When compared to discussions of essential infrastructure, Belfast's parks also hold alterative meanings to established defensive narratives associated with peace walls, self-policing community boundaries, and exclusionary spaces (Shirlow and Murtagh, 2006) (Fig. 5). We propose that parks are less politicised, as they act at a confluence of communal and formal (i.e. BCC) understandings of landscape functionality and are not burdened with the same socio-political meanings as interface

\footnotetext{
${ }^{3}$ The Connswater Greenway is a $\mathbf{f 4 0}$ million investment in a $9 \mathrm{~km}$ linear route in east Belfast that follows the course of the Knock, Loop and Connswater rivers, linking residential communities with retail/commercial/tourist spaces through a set of parks, green spaces and green links.
} 
zones in western and eastern parts of the city (Neill, 2006). For example, the Botanic Gardens and Ormeau Park (both located in less segregated areas), offer diverse recreational, aesthetic and sports facilities. This speaks to the discussion of physical and psychological accessibility proposed by Lynch (1972), who argued that access to, and design of, public spaces were influential factors in establishing value, and could override communal perceptions of exclusion. Thus, by framing parks as "non-political" spaces we can focus on their potential to provide amenities that generate community value outside existing political divisions.

Part of this process has been establishing our understanding of the city's physical architecture, which holds dualistic meanings. The peace walls can be considered to be a physical manifestation of defensible city planning aimed at controlling interaction (Newman, 1973), whereas parks can be interpreted as being more abstract social "actors" for, as noted, they have been largely, though not exclusively, absent from the discussions of control associated with the peace walls (Abdelmonem and McWhinney, 2015). Parks may therefore provide communities with access to amenities where they can exhibit agency over space and engage with the landscape (and other communities) in a more positive, yet controlled way. Whereas the peace walls, were used as clear demarcations of control by communities and the police/city authorities because they created physical segregation (Shirlow and Murtagh, 2006). Parks can therefore offer shared locations where interaction between communities can be promoted without the same level of conflict arising (Abdelmonem and McWhinney, 2015). Moreover, by approaching this debate using Lefebvre we identify a potential transition from control associated with existing spatial practices to a more dynamic representation of space reflecting changing communal understandings.

Based on the afore discussion, this paper proposes that Belfast's parks hold an alternative ethno-cultural meaning compared to other built and community spaces. This is seen in the exploration of how experiential interaction can lead to parks becoming places associated with inclusivity and/or functionality. Thus, parks do not display the same intensity of "territorial" control as other elements of built infrastructure limiting their role or promotion as defensible spaces (Byrne and Gormley-Heenan, 2014). Consequently, parks can be uncoupled, to some extent, from segregationist assessments of Belfast's landscape. Such a disassociation between how parks are viewed raises questions about how we debate and plan for future inclusivity and the utility of adopting the conceptual framing applied in this paper. Although Amin (2002) describes public spaces as places of transition that offer little meaningful contact between strangers, parks can be designed to promote interaction, as they form landscapes that can be considered as socio-culturally flexible (Cranz, 1982). Indeed, Waterworks Park is an evolving shared space due to the amenities it offers, especially when compared to the physical and socially constructed divisions seen within Alexandra 
Park. Both sites are located within the same community; however, the size, amenities, and level of co-option by users of Waterworks Park as a multi-purpose space provides greater scope for individuals and communities to find their "place" within it. Unfortunately, the ways in which park design facilitates interaction is not fixed and, accordingly, variation occurs in the societal values placed on these spaces (Lynch, 1981). This is especially prescient in Belfast, where parks are provided with comparable facilities to lower equitable resource distribution concerns (Rishbeth et al., 2018). Massey $(2005,9)$ explores these issues, proposing three approaches are pertinent to our discussion of Belfast:

(1) Understanding of space is an outcome of our interactions with it, a view present in contemporary debates of landscape use/functionality in Belfast;

(2) Co-existing uses are reflective of the contemporary society's diversity and should be applied to how we perceive parks; and

(3) Public space constantly evolves and is therefore relational to society's changing influences.

Massey can thus be read in alignment with Lynch and Lefebvre to propose that changing values placed upon public spaces, especially parks, provide agency for both the public and BCC to promote more shared, inclusive spaces.

In respect to Belfast, all three issues are reported in existent literature as constantly intersecting (Abdelmonem and McWhinney, 2015). Building upon Lynch, Banerjee (2001) extends this discussion, arguing as Lynch does, that the design of a space sets the context for interaction but does not lead directly to behavioural change. Shifts in behaviour are developed where individuals or communities "buy into" the aesthetic, amenity or ecological value of a park. This process may be moderated by existing ethno-cultural interpretations as witnessed on the Connswater Greenway and in Victoria Park where investments in landscaping, access and play/social amenities have promoted new uses. In Orangefield Park, signs of sectarian division remain, as the site hosts a "permitted" Unionist bonfire site thereby reinforcing a sense of localised ownership, despite the greenway's diverse population (Prior et al., 2014). Caveats therefore remain in the level of social engineering that park design can have on use, a critique also levelled at Newman and Lynch (Lynch, 1981).

Despite a growing focus on how we moderate use, access, and the role of amenities in developing understandings of place, it remains difficult to disengage from established perceptions of segregation in Belfast. This paper does not create a new, inclusive design approach but rather sets the foundation for such discussion, enabling a range of conceptual approaches to be utilised in 
future development decisions. We do, however, note that the use of play facilities, water features, benches, and other community-focussed amenities promote use by providing facilities that place social significance on public parks (Rishbeth, 2001).

The question of whether parks are being developed, managed and used as places that promote inclusivity remains. If we conceptualise parks from an understanding of the individual and communal activities therein using Lynch's (1960) approach to social significance, we can propose that they may not be tied to violence or segregation. We also argue that by embedding such a narrative within community and city-level policies, it becomes feasible for BCC to manage these spaces more inclusively by facilitating more effective forms of community buy-in. This, potentially, allows parks to be viewed within policy and community thinking as challenging traditional claims to territoriality, as an increasing awareness of the permeability of landscape borders can be evaluated against the physical boundaries that currently delineate community ownership (Gaffikin et al., 2010). Thus, the role of landscape and parks' design can become increasingly important, where an evolution away from naturalistic or pragmatic landscape design is replaced by greater focus on interactive and inclusive community or play elements (Rishbeth, 2001).

This would circumvent the domination of ethno-cultural power relationships explored by Murtagh (2011) and O'Dowd and Komarova (2011), who argue that there are ongoing links between behaviour, and centralised and communal control of physical space. It would also question the role of observation as the dominant form of authority proposed by Foucault, as although parks are inherently observed, the level of control exerted is less overt compared to other parts of cities (Abdelmonem and McWhinney, 2015; Byrne and Gormley-Heenan, 2014). Moreover, because this paper frames parks as locations for multitudinous interactions, BCC may be able to plan its management strategies more coherently for wider community interactions, as they are not as constrained by the limitations of meeting the needs of individual Catholic or Protestant communities.

Returning to Foucault's notional control of space and Newman's psychological discussion of defensible spaces, we argue that a softening of the parameters of exclusion is apparent in Belfast, as people increasingly engage with parks, especially in Ormeau, Victoria and Waterworks parks. Consequently, if parks become embedded within the city's development strategy and managed to service the wider community needs of all residents they can be promoted as shared and evolving spaces. The provision of recreational amenities within parks, although not without segregationist undertones can also be proposed as a method of moving beyond city, military or communal control once users take ownership of the facilities and not just the physical space (Gaffikin and Morrissey, 2011). This is, however, dependent on the city and its communities developing a greater 
understanding of how design and management can (a) promote behavioural change, (b) change over time and (c) identify what the key factors are that promote the use of these sites within and across communities (Dempsey et al., 2014).

Such a re-conceptualisation of parks can help to facilitate policy shifts, i.e. the Belfast Agenda, and personal or communal actions away from ethno-cultural behaviours associated with existing defensive architecture. The historic control exerted by the city and the police/military over physical space can potentially be downgraded, as local and individual awareness of the utility and functionality of parks is enhanced (Abdelmonem and McWhinney,2015). Through its broader development agenda and community engagement strategies Belfast can reposition how it conceptualises parks as "shared spaces". The outcome of this discussion is not only a shifting interpretation of space - similar in structure to Lefebvre's (1991) representational space - it also challenges existent notions of control/power through political, societal and physical built infrastructure. It further promotes the view that the wider "Belfast" context will continue to diversify and influence how people interact with its parks, and issues of exclusion and/or inclusion (Byrne and Gormley-Heenan, 2014).

This suggests an internalisation of interaction and experience that works in parallel to wider ethno-political contexts of space/place in Belfast. This is a significant shift, as it moderates the influence of the four areas of influence identified throughout this paper: physical/structural, societal, behavioural and political aspects of landscape. It also implies an interaction rather than a simple influence between physical/structural characteristics and the use of the city's parks. Such discussions include reflections on where and what access is available, behavioural actions associated with types of amenity, and communal and individual uses within them (Bollens, 2018). This complements how behaviour can be shaped by design, but downplays the overt role of political and ethno-cultural meanings attached to parks (Low et al., 2005).

The ongoing role of "politics" within our presentation of parks therefore becomes less influential, although it remains a contributing factor to understanding Belfast's parks. The notions of "control" over parks as observed through site visits, inherent in the presumptions associated with Foucault, appear to hold less influence on use, and can alternatively be framed by Lynch's "social signifiers" and Lefebvre's experiential understandings of space. There does, however, remain a parallel need to ensure that formal policy in Belfast retains a focus on parks, which can be actioned through their management or how they are integrated within redevelopment plans ( $O^{\prime}$ Dowd and Komarova, 2011). Accordingly, the promotion of individual associations of value and/or utility are more readily aligned with Lynch's assessments of space (Nagle, 2009). This view is growing in prominence, especially Amongst younger people (Shirlow and Murtagh, 2006), for example in the 
Waterworks and Falls Parks, as the ways in which people interact with parks for socialising, sports, and other recreational activities ${ }^{4}$ differ from historical understandings of exclusion associated with areas of north and west Belfast (Hickey, 2014).

What parks mean to people and whether this remains reflective of established understandings of place in Belfast provides scope to reconsider the ways in which perceptions, behaviour and experience differ. This allows us to move theoretically beyond Foucault and Newman, and engage with Lefebvre's experiential rationale of space focussing on how social meaning becomes attached to spaces (Nagle, 2009). This paper argues for the construction of a refined narrative that challenges the established consensus that all Belfast's landscapes hold negative or ethno-cultural meanings. The variability in assessments of parks, as explored in the literature, suggests that existing interpretations of space in Belfast related to segregation may have been diluted because these places possess a more diverse set of social meanings. It may also be influenced by design, socio-economic change and development policies, as reported in existent literature (Byrne and Gormley-Heenan, 2014). This, we argue, implies that a greater subtlety is being established with regards to how social signifiers are attached to parks compared to explorations of other parts of Belfast's infrastructure.

\section{Conclusion}

How we perceive space in Belfast is changing. There is a growing understanding of the role that interactions with public space play in a city that has been historically, physically and socially divided. Our discussion of parks differs, as it questions whether existing perceptions of physical space should be reconsidered formally by $B C C$ and societally by local communities. We argue that, whilst an established narrative of public space suggests that they have been thought of as exclusionary, there is a developing appreciation in Belfast that not all spaces possess the same societal or physical significance. Moreover, although the conceptual discussion herein proposed may not provide BCC with an explicit framework to rethink their management of parks, it does highlight how differing social meanings are attached to place, as discussed in terms of observations, interaction and inclusion. Newman and Foucault's approaches may support existing notions that a level of control over public space is visible in Belfast, however, through engagement with Lynch and Lefebvre, a more evolutionary appreciation of landscape can be developed. Perceptions of parks are, therefore, diversifying. As Belfast's demographic structure changes and moves away from historical sectarian positions, we propose a growing interactivity between individuals, communities and its landscape.

\footnotetext{
${ }^{4}$ Users also report issues with anti-social behaviour associated with young people drinking, taking drugs and intracommunity fighting. However, these are not seen to be associated with ongoing sectarianism.
} 
The use of parks as a location for this discussion has illustrated that a reassessment of spatial control, in terms of design and community interactions with respect to place attachment, can be made. Consequently, we argue that though historical ethno-community associations with "place" remain visible, existing sectarian assumptions of place can, by using Lynch's (1960) assessment of social signifiers and Lefebvre's (1991) representative space concept, be challenged. This is framed against the construction of defensive landscapes debated by Foucault (1991) and Newman (1973), illustrating how the location, architecture, and interactivity of parks can be considered segregationist or inclusive. This, we conclude promotes the use of parks as spaces of recreation, engagement and interaction, and shifts the social significance of space from one of exclusion to inclusion. Although we do not propose a new typology of park design or management, we have described the conceptual parameters that could be used to facilitate further investigations into the inclusivity of the city's parks.

\section{Acknowledgement}

The author is grateful to the School of Environment, Education \& Development at the University of Manchester for seed corn funding to undertake initial research for this paper in 2017. 


\section{Bibliography}

ABDELMONEM, M. G., \& MCWHINNEY, R. (2015). In search of common grounds: Stitching the divided landscape of urban parks in Belfast. Cities, 44, 40-49.

AMIN, A. (2002). Ethnicity and the Multicultural City: Living with Diversity. Environment and Planning A, 34, 6, 959-980.

BANERJEE, T. (2001). The Future of Public Space: Beyond Invented Streets and Reinvented Places. Journal of the American Planning Association, 67, 1, 9-24.

BELFAST CITY COUNCIL. (2014). Your future city: The Belfast Agenda. A draft for consultation. Belfast. BERGER, J. (1972). Ways of Seeing. London: Penguin.

BOAL, F. (1994). Encapsulation: Urban dimensions of national conflict. In S. In Dunn (Ed.), Managing Divided Cities (p. 30-40.). London: Keele University Press.

BOLLENS, S. (2018). Trajectories of Conflict and Peace Jerusalem and Belfast Since 1994. London: Routledge.

BRUNSON, L., KUO, F. E., \& SULLIVAN, W. C. (2001). Resident Appropriation of Defensible Space in Public Housing: Implications for Safety and Community. Environment and Behavior, 33, 5, 626652.

BRYAN, D. (2003). Belfast: Urban space, "policing" and sectarian polarization. In J. Schneider \& I. Susser (Eds.), Wounded Cities (pp. 251-269). Oxford: Berg.

BURGESS, J., HARRISON, C., \& LIMB, M. (1988). People, Parks and the Urban Green: A Study of Popular Meanings and Values for Open Spaces in the City. Urban Studies, 25, 6, 455-473.

BYRNE, J., \& GORMLEY-HEENAN, C. (2014). Beyond the walls: Dismantling Belfast's conflict architecture. City, 18, 4-5, 447-454.

CABE SPACE. (2005). Start with the park: Creating sustainable urban green spaces in areas of housing growth and renewal. London: CABE Space.

CRANZ, G. (1982). The Politics of Park Design: A History of Urban Parks in America. Cambridge: MIT Press.

CUNNINGHAM, T. (2014). Changing direction: Defensive planning in a post-conflict city. City, 18, 4-5, 455-462.

DEMPSEY, N., SMITH, H., \& BURTON, M. (2014). Place-Keeping: Open Space Management in Practice. London: Routledge.

EVANS, J., \& JONES, P. (2011). The walking interview: Methodology, mobility and place. Applied Geography, 31, 2, 849-858.

FOUCAULT, M. (1991). Discipline and Punish: The Birth of the Prison (Penguin Social Sciences). Penguin.

GAFFIKIN, F., MCELDOWNEY, M., \& STERRETT, K. (2010). Creating Shared Public Space in the Contested City: The Role of Urban Design. Journal of Urban Design, 15, 4, 493-513.

GAFFIKIN, F., \& MORRISSEY, M. (2011). Planning in Divided Cities. Oxford: Wiley-Blackwell.

GRAHAM, S., \& HEALEY, P. (1999). Relational concepts of space and place: Issues for planning theory and practice. European Planning Studies, 7, 5, 623-646.

GREEN, A., SHUTTLEWORTH, I., \& LAVERY, S. (2005). Young people, job search and local labour markets: the example of Belfast. Urban Studies, 42, 2, 301-324.

HETHERINGTON, K. (1998). Expressions of Identity: Space, Performance and Politics. London: Sage.

HICKEY, R. (2014). The psychological dimensions of shared space in Belfast. City, 18, 4-5, 440-446.

JACOBS, J. (1961). The Death and Life of Great American Cities. New York: Vantage Books.

KOMAROVA, M., \& BRYAN, D. (2014). Introduction: Beyond the divided city: policies and practices of shared space. City, 18, 4-5, 427-431.

LACHMUND, J. (2013). Greening Berlin: the co-production of science, politics, and urban nature. Cambridge: MIT Press.

LEDRUT, R. (1973). Les Images de la Vile. Paris: Anthropos.

LEFEBVRE, H. (1991). The Production of Space. Wiley-Blackwell. 
LEONARD, M. (2004). Bonding and Bridging Social Capital: Reflections from Belfast. Sociology, 38, 5, 927-944.

LOW, S., TAPLIN, D., \& SCHELD, S. (2005). Rethinking urban parks, public space and cultural diversity. Austin: University of Texas Press.

LYNCH, K. (1960). The Image of the City (Harvard-Mit Joint Center for Urban Studies). MIT Press.

LYNCH, K. (1972). Openness of open space. In T. Banerjee \& M. Southworth (Eds.), City sense and city design: Writings and projects of Kevin Lynch (pp. 396-412). Cambridge: MIT Press.

LYNCH, K. (1981). A Theory of Good City Form. Boston: MIT Press.

MADDEN, D. J. (2010). Revisiting the End of Public Space: Assembling the Public in an Urban Park. City \& Community, 9, 2, 187-207.

MASSEY, D. (2005). For Space. London: Sage.

MELL, I. (2018). Financing the future of green infrastructure planning: alternatives and opportunities in the UK. Landscape Research, 43, 6, 751-768.

MORRISSEY, M., \& GAFFIKIN, F. (2006). Planning for Peace in Contested Space. International Journal of Urban and Regional Research, 30, 4, 873-893.

MURTAGH, B. (2002). The Politics of Territoriality: Policy and Segregation in Northern Ireland. Aldershot, UK: Palgrave Macmillan.

MURTAGH, B. (2011). Desegregation and Place Restructuring in the New Belfast. Urban Studies, 48, 6, 1119-1135.

NAGLE, J. (2009). Sites of Social Centrality and Segregation: Lefebvre in Belfast, a "Divided City." Antipode, 41, 2, 326-347.

NASSAUER, J. (1995). Culture and changing landscape structure. Landscape Ecology, 10, 4, $229-237$.

NEILL, W. J. V. (2006). Return to Titanic and lost in the maze: The search for representation of 'postconflict' Belfast. Space and Polity, 10, 2, 109-120.

NEILL, W. J. V. (2010). Belfast - Rebranding the "Renaissance City": from "the Troubles" to Titanic Quarter. In J. Punter (Ed.), Urban Design and the British Urban Renaissance (pp. 305-322). London: Routledge.

NEILL, W., FITZSIMONS, D., \& MURTAGH, B. (1995). Reimaging the Pariah City: Urban Devleopment in Belfast \& Detroit. Aldershot: Avebury.

NESTA. (2016). Learning to rethink parks. Nesta, London, UK.

NEUMAN, M. (1998). Planning, Governing, and the Image of the City. Journal of Planning Education and Research, 18, 1, 61-71.

NEWMAN, O. (1973). Defensible Space: People and Design in the Violent City. London: Architectural Press.

O'DOWD, L., \& KOMAROVA, M. (2011). Contesting Territorial Fixity? A Case Study of Regeneration in Belfast. Urban Studies, 48, 10, 2013-2028.

PERKINS, D. D., WANDERSMAN, A., RICH, R. C., \& TAYLOR, R. B. (1993). The physical environment of street crime: Defensible space, territoriality and incivilities. Journal of Environmental Psychology, 13, 1, 29-49.

PICKETT, B. (2005). On the Use and Abuse of Foucault for Politics. Lanham, Maryland: Lexington Books.

PL ØGER, J. (2008). Foucault's Dispositif and the City. Planning Theory, 7, 1, 51-70.

PRIOR, L., SCOTT, D., HUNTER, R., DONNELLY, M., TULLY, M. A., CUPPLES, M. E., \& KEE, F. (2014). Exploring lay views on physical activity and their implications for public health policy. A case study from East Belfast. Social Science \& Medicine, 114, 73-80.

RALLINGS, M.-K. (2014). 'Shared space' as symbolic capital: Belfast and the 'right to the city'? City, 18, 4-5, 432-439.

RISHBETH, C. (2001). Ethnic Minority Groups and the Design of Public Open Space: An inclusive landscape? Landscape Research, 26, 4, 351-366.

RISHBETH, C., GANJI, F., \& VODICKA, G. (2018). Ethnographic understandings of ethnically diverse neighbourhoods to inform urban design practice. Local Environment, 23, 1, 36-53. 
RYBCZYNSKI, W. (1999). Why we need Olmsted again. Wilson Quarterly, 23, 3, 98-106.

SHIRLOW, P. (2006). Belfast: The 'post-conflict' city. Space and Polity, 10, 2, 99-107.

SHIRLOW, P., \& MURTAGH, B. (2006). Belfast: Segregation, Violence and the City. London, UK: Pluto Press.

SILVA GOUVEIA, A. P., LENA FARIAS, P., \& SOUZA GATTO, P. (2009). Letters and cities: reading the urban environment with the help of perception theories. Visual Communication, 8, 3, 339-348.

STAEHELI, L., \& MITCHELL, D. (2008). The People's Property? Power, Politics and the Public. Abingdon: Routledge.

TATE, A. (2015). Great City Parks, 2nd Edition (with Marcella Eaton) (2nd ed.). London, UK: Routledge.

TAYLOR, R., GOTTFREDSON, S., \& BROWER, S. (1984). Block Crime and Fear: Defensible Space, Local Social Ties, and Territorial Functioning. Journal of Research in Crime and Delinquency, 21, 4, 303-331. 


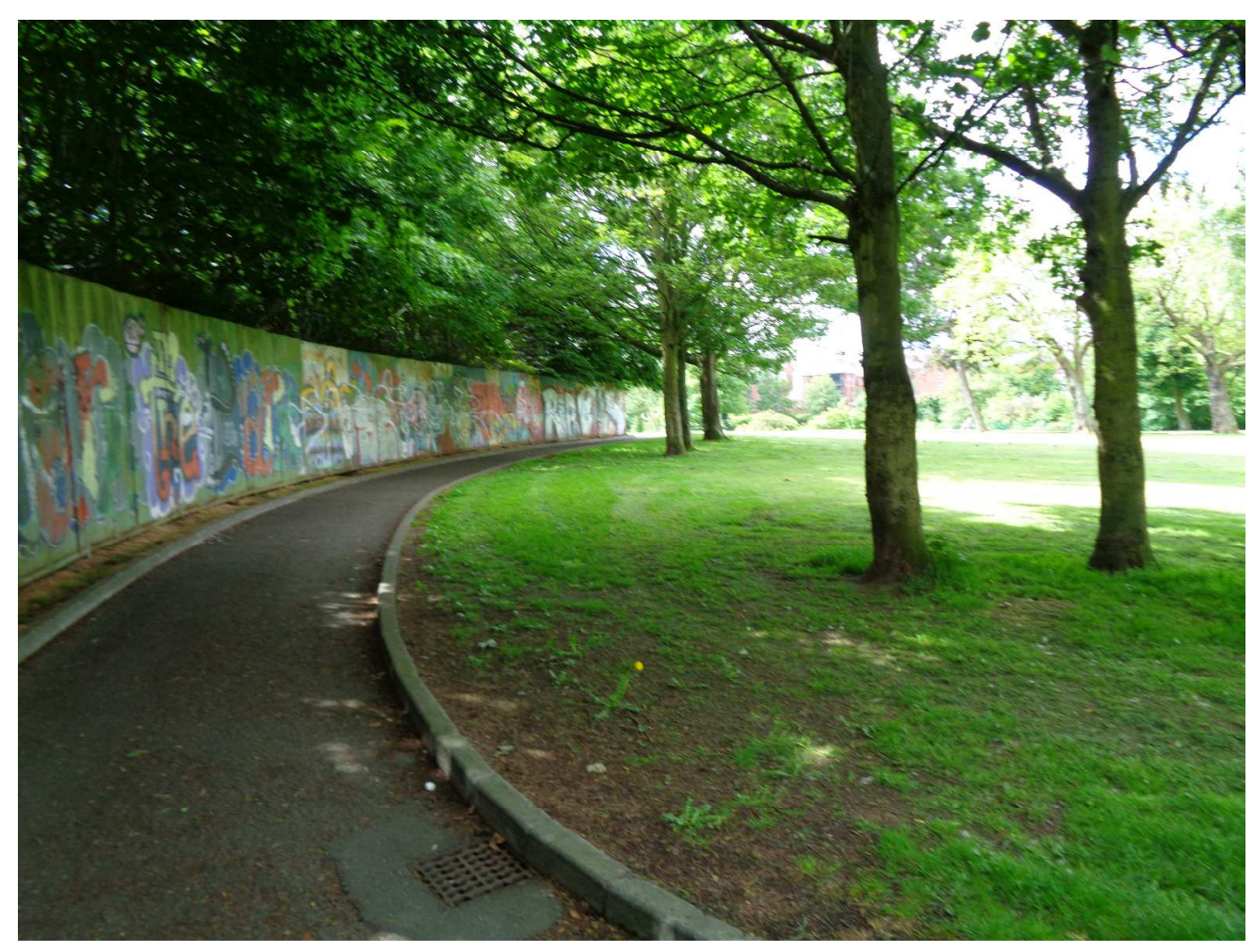

Fig. 3. Peace Wall in Alexandra Park

$280 \times 210 \mathrm{~mm}(300 \times 300 \mathrm{DPI})$ 


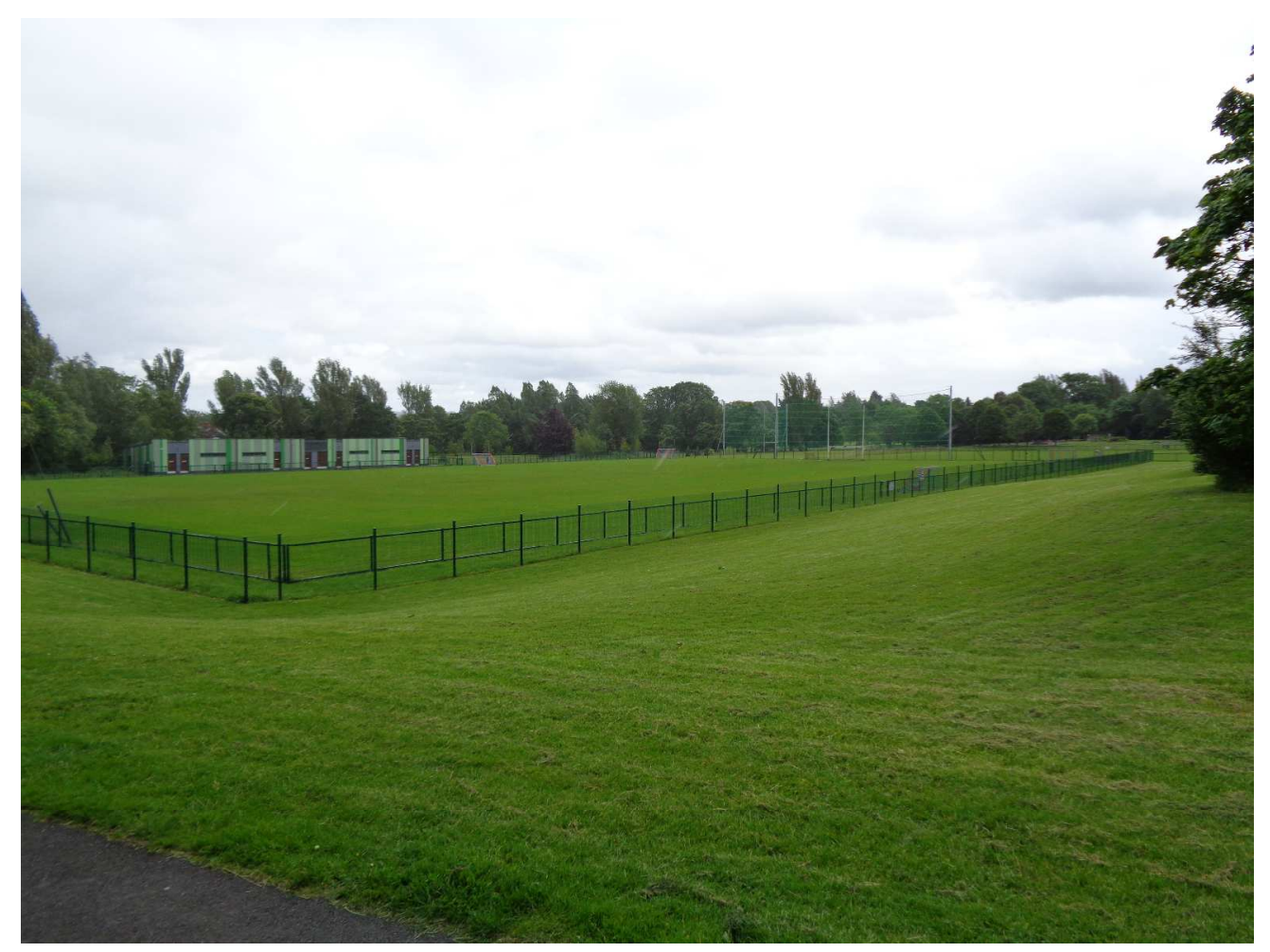

Fig. 4. GAA facilities in Musgrave Park $280 \times 210 \mathrm{~mm}(300 \times 300 \mathrm{DPI})$ 


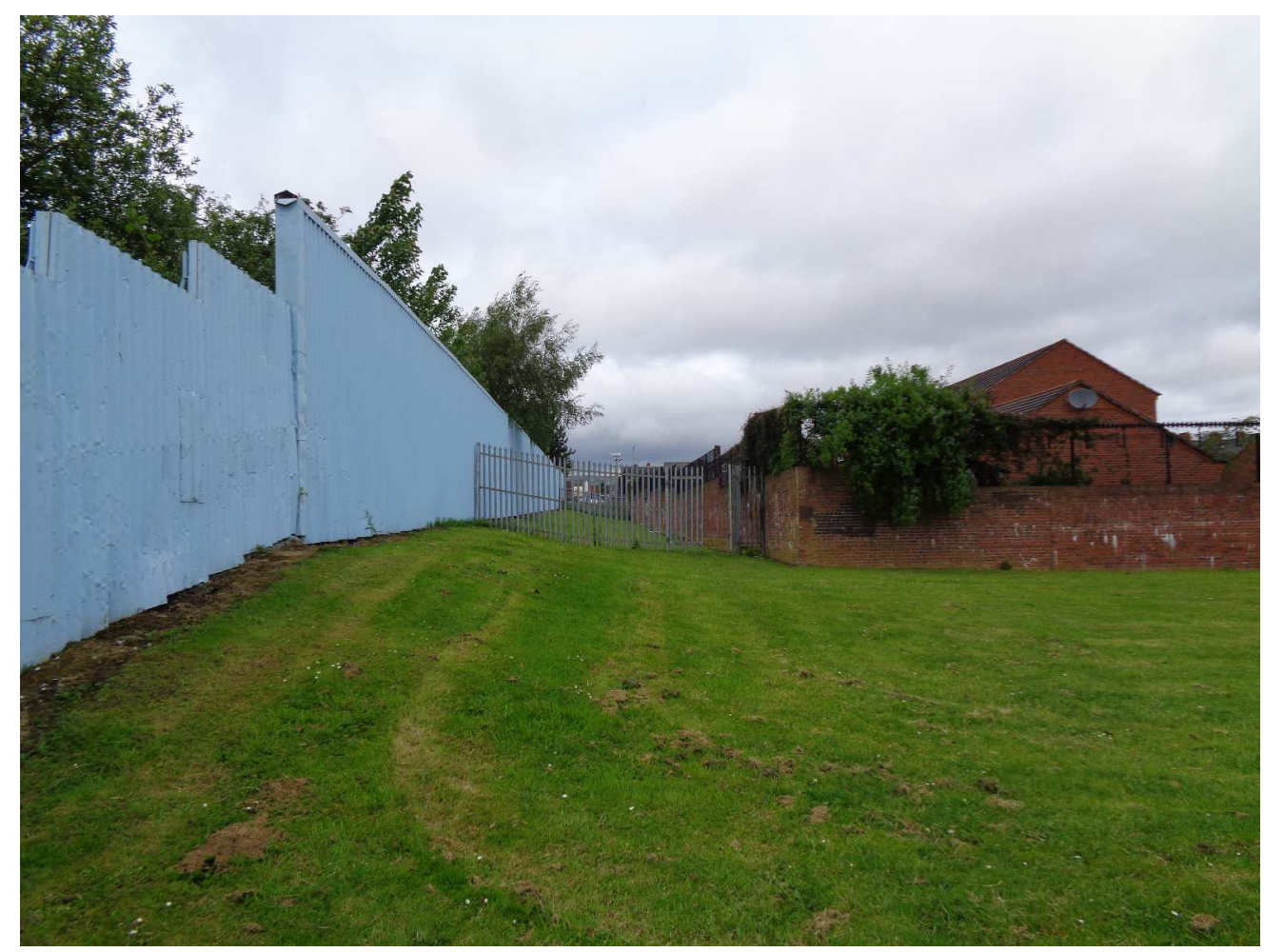

Fig. 5. Defensive architecture and green space $280 \times 210 \mathrm{~mm}(300 \times 300 \mathrm{DPI})$ 